University for Business and Technology in Kosovo

UBT Knowledge Center

UBT International Conference

2018 UBT International Conference

Oct 27th, 10:45 AM - 12:15 PM

\title{
Assessment of education, attitudes and financial behavior towards financial decision-making - The case of students with economic aid
}

\author{
Perseta Grabova \\ University of Tirana, persetagrabova@feut.edu.al \\ Meril Canameri \\ University of Tirana, merilcanameri@gmail.com \\ Merlina Guni \\ University of Tirana, merlinaguni@hotmail.com \\ Jona Hoxha \\ University of Tirana, jona.hoxha9@gmail.com
}

Follow this and additional works at: https://knowledgecenter.ubt-uni.net/conference

Part of the Business Commons

\section{Recommended Citation}

Grabova, Perseta; Canameri, Meril; Guni, Merlina; and Hoxha, Jona, "Assessment of education, attitudes and financial behavior towards financial decision-making - The case of students with economic aid" (2018). UBT International Conference. 281.

https://knowledgecenter.ubt-uni.net/conference/2018/all-events/281

This Event is brought to you for free and open access by the Publication and Journals at UBT Knowledge Center. It has been accepted for inclusion in UBT International Conference by an authorized administrator of UBT Knowledge Center. For more information, please contact knowledge.center@ubt-uni.net. 


\title{
Assessment of education, attitudes and financial behavior towards financial decision-making - The case of students with economic aid
}

\author{
Perseta Grabova ${ }^{1}$, Meril Canameri $^{2}$, Merlina Guni ${ }^{3}$, Jona Hoxha ${ }^{4}$ \\ ${ }^{1}$ University of Tirana, Faculty of Economy, Department of Finance, Tirana, Albania \\ ${ }^{2}$ University of Tirana, Faculty of Economy, Department of Finance, Tirana, Albania \\ ${ }^{3}$ University of Tirana, Faculty of Economy, Department of Finance, Tirana, Albania \\ ${ }^{4}$ University of Tirana, Faculty of Economy, Department of Finance, Tirana, Albania
}

\begin{abstract}
In today's society, individuals face financial pressures since a very young age. International studies in the field of behavior and financial literacy have shown that individuals who acquire financial knowledge at an early age will be able to manage their money, make the right financial decisions, and contribute to the financial stability of their country. Other studies argue that limited financial literacy is an important obstacle for low-income households to require products and financial services as they do not know or are unfamiliar with such products and services and consequently, they cannot obtain them. By analyzing the perception of the students who get economic aid referring to money and wealth, it has been observed the impact of such factors as financial literacy, emotions, financial behavior on using money or financial decisionmaking. To identify the impact of these factors, qualitative data have been collected through interviews of the students with economic aid from the Faculty of Economics and the Faculty of Foreign Languages of the University of Tirana. In general, the findings of this study demonstrate the importance of financial education of the family. By understanding how factors such as students' financial literacy, parental influence on their financial literacy, or emotions can contribute to enabling them to make the right financial decision. While governmental policies still give people responsibility for saving and investing then financial literacy needs to be given a greater importance at an early age. The existence of differences in the financial knowledge of the young age group of people has been documented. Gender, level or type of education, family characteristics influence the development of these differences, which should be taken into account by policy makers aiming at improving financial literacy.
\end{abstract}

Keywords: financial literacy, behavioral, students, family, economic aid, Albania. 


\section{Introduction}

In today's society, individuals face financial pressure since a very young age. International studies in the field of behavior and financial education have shown that individuals who acquired financial knowledge since an early age will be able to manage their money, make the right financial decisions, and contribute to the financial stability of their country [16].

Financial literacy is recognized internationally as an important element that affects the stability and economic growth of a country. For Albania, the rapid growth of household debt before the global financial crisis and the subsequent growth of nonperforming loans proved that households use financial services but they lack the knowledge and experience to manage their finances. The debt trend in Albania makes the need for more education about financial issues indispensable. Debt growth has become a critical issue and young people in particular need to be equipped with financial knowledge before embarking on their high school experience, a time that may coincide with the first important experiences regarding financial decision making. Beyond that, Lusardi and Tufano (2009) [17] emphasize the need for financial literacy as financial markets offer new and complex products and the responsibility for investing and saving has shifted from the government and the employer to the individual. Under these circumstances young people or students are facing or will face in the near future with decisions such as: obtaining a mortgage loan, investing in mutual funds, savings, life and health insurance, income statement etc., while their knowledge in this regard seems very low [18, 19] and potentially inadequate to deal with ever more complex financial markets and financial products. Different scholars have also stressed the importance of providing financial education programs in promoting the use of financial services especially by low-income families [29].

Researchers such as Cole, Sampson, \& Zia, (2010) [5] have found that financial education is an essential factor which affects and encourages individuals to use financial services and products. They came to the conclusion that financial literacy can be considered as a complementary factor in increasing the use of financial services by individuals with a limited income. In addition to the importance of financial education in building individuals' financial skills, other researchers have identified the financial behavior of parents as a factor affecting student financial behavior [26]. Exposing children from an early age to the management of family assets helps in increasing the level of knowledge and financial skills of future generations.

The main studies in the field of financial literacy are mostly focused on identifying the links that exist between financial skills, financial knowledge, financial behavior and socio-economic and demographic factors. In Albania, despite the modest number of studies undertaken in this regard, there has not yet been undertaken any research focused on individuals with limited income. Therefore, we considered interesting to understand how factors such as: financial education of students, parental influence on their financial education, or financial behavior affect their financial decision making, and then to evaluate the possibility of using the potential of these individuals to secure savings and investments in economy as well as to manage the risks they will face in the future. The above issues will be the objectives of this paper. 


\section{Financial Education and Financial Literacy Skills}

In literature the term financial literacy is used as a substitute for the term financial education or financial knowledge. However, what is noticed in the literature is that financial literacy goes beyond financial education. Many authors argue that financial literacy consists of two elements: the first relates to financial education or financial knowledge related to understanding, and the second element relates to the application of financial knowledge acquired, that is, financial management [10]. Remund (2010) [23] reviewed many research studies conducted since 2000 and concluded that conducting financial literacy research was a major challenge as there was no standard definition well defined to refer to this concept.

In the adoption of High Level Principles on National Financial Education Strategies, the OECD (2013) [20] has proposed a definition of the term financial literacy that it includes a combination of awareness, knowledge, skills, attitudes, and behaviors that are needed to make sound financial decisions affecting the achievement of the financial well-being of the individual and society as a whole. Whereas the term financial education refers to the knowledge gained in the life cycle during the creation of human capital while developing subjects or topics related to expenditure and income management, savings and investments, tax management, etc. that is knowledge obtained which affect the financial literacy (qualification) of the individual.

\section{Financial Education as part of the University Curriculum}

Financial literacy has been and continues to remain in the attention of many scholars and international organizations as a matter of great concern around the world. Its importance becomes even more evident nowadays when financial markets are developing at rapid rates, offering increasingly complex choices and when the development of the financial system plays an important role in the economic development of the countries. Financial literacy plays an even more decisive role in countries in transition like Albania, where the financial system is in the initial stages of its development and has potential for further development.

Relevant literature is increasingly showing that financial literacy is at low unacceptable levels, all over the world especially observed among the poor people living in developing countries. There is an increasing concern about the need for financial education of individuals in general and individuals with limited income in particular, The low level of financial inclusion of this category is affected by low levels of income, low level financial literacy and demographic factors such as location [28]. Shim, Serido, Bosch, and Tang (2013) [27] have noted that "a well-established financial identity will facilitate the development of young people's positive attitudes and behaviors in a society, while the lack of a clear financial identity can lead to the development of risky financial behaviors."

According to the results of the studies conducted at the national level by the Ratings Services Global FinLit Survey (S \& P) (2014) [11,19] the level of financial literacy in Albania results to be very low. Standard \& Poor's (2014) [11] state that only $14 \%$ of adults in Albania have financial education and only 1 in 3 adults 
understand the basic financial concepts, while the OECD survey results point to a lack of financial knowledge among a large part of the population. Apart from that we observed that there is considerable room for improvement in terms of behavior and financial attitudes [19]. The main efforts to increase financial literacy have been made by the Bank of Albania, which for a number of years has implemented a number of projects / competitions for youth education. With regard to financial education, a curriculum on "Personal Finance in Your Hands" has been integrated in the high school system since 2011, including a total of 36 teaching hours for high school students. The module acquaints students with the world of personal finance and its goal is to inform them and develop the skills they need to manage money in the most lucrative way.

A widely asked question in the literature is "What is the most appropriate period of financial education for young people?" The literature review identified that: "...... it is more beneficial to provide financial education before individuals engage in contracts and before they start making financial decisions." [18]. Other studies have also shown that students in the first year of higher education had low levels of financial education [19] and that high school curricula did not prepare them to make basic financial decisions. However, it has been suggested that the lack of effectiveness of financial education in high schools may also be due to the lack of opportunity to implement what is learned [2]. Accompanying financial education of students with the ability to apply the knowledge they have gained, can provide a stronger impact on their financial behaviors. This result supports the idea of providing financial knowledge even in the first year of higher education, a phase in which students need to make financial decisions regarding expenditure management, debt, limited income management, etc. [21].

In the circumstances when studies have shown that financial education at high school is not effective [2], higher education institutions should consider the possibility of its involvement efficiently, regularly in curricula in all branches of study, since the first semester of their studies. Kezar and Yang (2010) [12] agreed, saying that "financial education should be appreciated as a vital skill, as a necessity for citizenship as a decisive intellectual competence as an essential component of university education". In the case of the University of Tirana, only the students of the Faculty of Economy of the Finance program are taught the subject "Personal Finance", a non-compulsory course which is conducted in the third year of the first cycle of studies.

\section{The impact of socio-economic and demographic factors on financial literacy}

There may be many factors that affect the level of financial literacy that a person has acquired. Empirical data demonstrate a positive impact of financial literacy on the behavior and financial status of individuals. Thus, various studies show that individuals with a high level of financial education have better results in budgeting, saving money and control of their spending [22], handling mortgage loans and other debts [14] and successful accumulation of wealth /welfare [5], financial participation in financial markets [14]. On the other hand, numerous studies have drawn 
conclusions on demographic and socio-economic factors affecting the level of financial literacy and the way of their affect. Thus many authors $[14,1]$ converge to the same conclusions. According to their results, women, the elderly and the poor generally have a lower level of knowledge and financial literacy than men. Also, young people and the elderly generally know less about the financial aspect than the middle age people. On the other hand, the level of financial education is positively correlated with the highest levels of education [19] and income. Those who do not have a higher education are less likely to get acquainted with the basic financial concepts [15].

According to OECD (2013) [20], financial education increases the ability of individuals to make informed financial decisions and in the case of the poor it would be an advantage for them to manage their financial affairs. The outcome of financial decisions has important impact on financial security and the standard of living of poor families. Therefore, poor families with a good level of financial literacy can manage their financial matters more carefully than those who do not have these skills. Researchers $[13,5]$ found that financial education is a factor of significant impact on the level of financial inclusion. Atkinson and Messy, (2013) [1] note that the main cause of financial exclusion of the poor families is attributed to lack of information about different types of financial products and /or low levels of trust and behavior that hinder the use of the formal financial products. Furthermore Cole, Sampson \& Zia, (2009) [5] argue that limited financial education is a major obstacle to the demand for financial products and services. The poor families who are not familiar with or who are not aware of such products and services will not require them.

Nowadays, young people face ever-increasing financial pressures since an early age, and in spite of this, families do not involve their children in financial family affairs or decision-making. "..... it seems that parents do not talk to their children about financial knowledge and competence" [8]. On the other hand, Shim et al. (2009) [25] stated that the role of parents in a student's financial literacy is greater than a student's work experience or financial education that can be obtained in preuniversity education. Heckman and Grable (2011) [9] conducted a study to find the factors that influence financial literacy level of a student. In this study, it was identified that factors such as income, parental attitudes towards debt, and the status of financial dependency on parents have a positive correlation with financial knowledge and financial literacy.

Chinen and Endo (2012) [4] agree on the theory that the field of study is an important factor in differences in levels of financial education and financial literacy. They argue that students who had completed high-level studies mainly in branches related to "figures" such as in the field of economics had a higher level of financial education versus "non-numeric" degrees (e.g., arts sciences social or education). Even according to the study carried out in the case of Albania, by Nano (2014) [19], students studying finance, agribusiness and economics had more accurate answers to questions related to financial literacy compared to the students studying journalism, history-geography or medicine. 


\section{$4 \quad$ Method and Analysis of Data}

The students who participated in the study were selected from the database of the students who receive scholarships as financial aid from the Faculty of Economics and Foreign Languages Faculty. We obtained the students records from the respective finance faculty offices. Before conducting the interviews, the Finance Office of each faculty were introduced to the purpose of the study.

Given the objectives of the study referring to the subjective experience of the students and their families with regard to financial decision making, we considered the method of interviews as the appropriate one, as it aimed at discovering and reconstructing the complex connections of the various sides of a phenomenon. We engaged the participants in in-depth interviews, not to substantiate any hypothesis or to get the answers of the questions, but to understand the experiences, perspectives of each participant, and the significance of their experiences. Through interviews conducted in January-February 2018, there were obtained words and observations that we have presented in the form of words and sentences. Flick (2009) [7] links the importance and success of semi-open interviews conducted face-to-face with the fact that participants' views are more complete and clear as compared to a non-face-toface questionnaire. Before each interview, we explained to the participants that some questions were of a sensitive and personal nature. All the participants were informed that the answer to the questions was voluntary and withdrawal from the study could be done at any time without any risk to them. They were given the opportunity to ask questions about the objectives of the study and the procedures of the interview. We coded all the participants' responses to ensure proper confidentiality concerning the study. During the interviews, an audio device was used to record them, in order to provide accurate information as well as the option to review the interviews at a later time if forgotten or lost information would be required. The sample in the study consisted of 15 students from the Faculty of Foreign Languages and 15 students from the Faculty of Economics, University of Tirana.

Table 1 displays demographic data referring to the participants of the study. Their age ranged from 19 to 21 years of age, and 25 participants belonged to the female gender while 5 of them were of male gender. Eight students from the sample reported that they were born and spent their childhood in the city of Tirana while the other students were from Tropoja (4 students), Durrës (4 students), Kukës (3 students), Berat (5 students), Shkodra (2 students), Peqini (2 students), Kruja (2 students).

The participants were asked about their employment and their financial behavior. The data showed that 10 students were employed, 9 it of them worked full-time while one worked part-time. Also the participants in the study were asked if their family owned the dwelling they lived in and it resulted in a figure of $46.7 \%$ whereas about $53.3 \%$ of the families of the participants lived in rented dwellings. All participants reported that their families receive from the state economic aid including their scholarship.

We decided to hold semi-open interviews intending to enable the participants to explain their relationship with money and financial decision-making in a free way. Full structuring of the questions would make the process difficult, because the participants' thoughts and ideas and the differences between the experiences and 
perceptions of each of them were not known in advance. First we recorded the interviews which lasted from 30 minutes to 1 hour and then transcribed them.

Table1: Demographic Data

\begin{tabular}{|c|c|c|c|c|c|c|}
\hline \multicolumn{2}{|c|}{ Gender } & \multirow{2}{*}{$\begin{array}{l}\% \\
83.4 \%\end{array}$} & \multirow{2}{*}{$\begin{array}{l}\text { No } \\
25\end{array}$} & \multirow[t]{2}{*}{ Employment } & \multirow{2}{*}{$\begin{array}{l}\% \\
30 \%\end{array}$} & \multirow{2}{*}{$\begin{array}{l}\text { No } \\
9\end{array}$} \\
\hline- & Female & & & & & \\
\hline- & Male & $16.6 \%$ & 5 & $\begin{array}{l}\text { - Part-time } \\
\text { - Unemployed }\end{array}$ & $\begin{array}{l}3.3 \% \\
66.7 \% \\
\end{array}$ & $\begin{array}{l}1 \\
20\end{array}$ \\
\hline \multicolumn{2}{|c|}{$\begin{array}{c}\text { Place of } \\
\text { Birth/Origin }\end{array}$} & $\%$ & No & Family's dwelling & $\%$ & No \\
\hline- & Tiranë & $26.6 \%$ & 8 & Rented & $53.3 \%$ & 16 \\
\hline- & Tropojë & $13.3 \%$ & 4 & Owned & $46.7 \%$ & 14 \\
\hline- & Durrës & $13.3 \%$ & 4 & & & \\
\hline- & Kukës & $10 \%$ & 3 & & & \\
\hline- & Berat & $16.7 \%$ & 5 & & & \\
\hline- & Shkodër & $6.7 \%$ & 2 & & & \\
\hline- & Peqin & $6.7 \%$ & 2 & & & \\
\hline- & Krujë & $6.7 \%$ & 2 & & & \\
\hline
\end{tabular}

The interviews conducted with the participants were divided into four parts: the first part was related to demographic data, such as age, sex, housing, family composition, employment status, if they had a savings account as well as demographic data related with the family (the status of the parent's employment, the family's income, the type of the parents' employment). In the second part of the interview each participant was asked to describe his/her family's experience and behavior with money, the family's economic prospects and financial behaviors. For example: who makes the family financial decisions, how the household manages the savings, how the family makes the decisions to spend and save, the child's perception of family finances during difficult economic times, the various messages that the family has received on saving and financial education, details about their experiences in terms of spending or family investment etc. The third part of the interview was related to assessing the student's financial behavior by identifying how they obtain their income, where they deposit money, student's perception of money and savings, their perceptions about their future related to savings and investments, as well as to identifying some of their short and long term financial goals. The fourth part of the interview aimed at assessing the level of financial knowledge of students participating in the study, for example: Have you ever heard of the time value of money? What is inflation and how it can affect your decision-making? When talking about future investments, what are some investment alternatives you can mention? Etc. We adopted the questions of the interviews from past studies [14], considering them as reliable and valid. In order to measure the financial literacy, we observed the level of knowledge, skills, attitude and behaviour as adopted from Atkison and Messy (2012) [1] and Lusardi and Mitchell (2011) [14].

Creswell (2009) [6] summarizes the eight procedures of the validation of the study which are most frequently used during interviews. He states that not all of these procedures should necessarily be used to ensure the validity of a study, but taking into 
account as many of them as possible, increases the validity of the study. Four out of the eight procedures were applied in conducting the interviews. Reviewing the findings to define their qualitative accuracy: Some descriptions of the interviews were presented to the participants so that they could confirm their accuracy and authenticity. Clarifying prejudices: At the beginning of the study we included the data on gender, cultural group and socio-economic group each participant belonged to. Spending a long time in the field: This helped to understand the phenomenon that we were elaborating, thus adding the reliability of the study. Review of findings by the scientific leader: A review of the findings during the course of the study was carried out by the scientific leader to avoid prejudices during the process of conducting the study and to provide his views on this study. This strategy that involves interpreting someone views besides the researcher adds value to the study. In addition to the validation procedures, in order to increase the credibility of this study, transcripts of interviews were carefully scrutinized in order to avoid mistakes. Apart from that we made a double control of the codes used during the interviews.

We chose the thematic analysis as an appropriate method because it is commonly used to describe, analyze, and report topics and models in data [3]. Table 2 describes the steps in which this analysis was conducted. Using this theoretical approach while conducting the interview, the responses to the questions asked in the previous interviews provided information to design new questions that could be addressed to participants in the latter interviews. Our purpose of this qualitative study was not to generalize the results but to study the phenomenon in depth. Moreover, it would be very useful to conduct other studies in this area to gather data and knowledge as well as to compare them with the findings of this study

Tabela 2. Phases of data analysis and process description

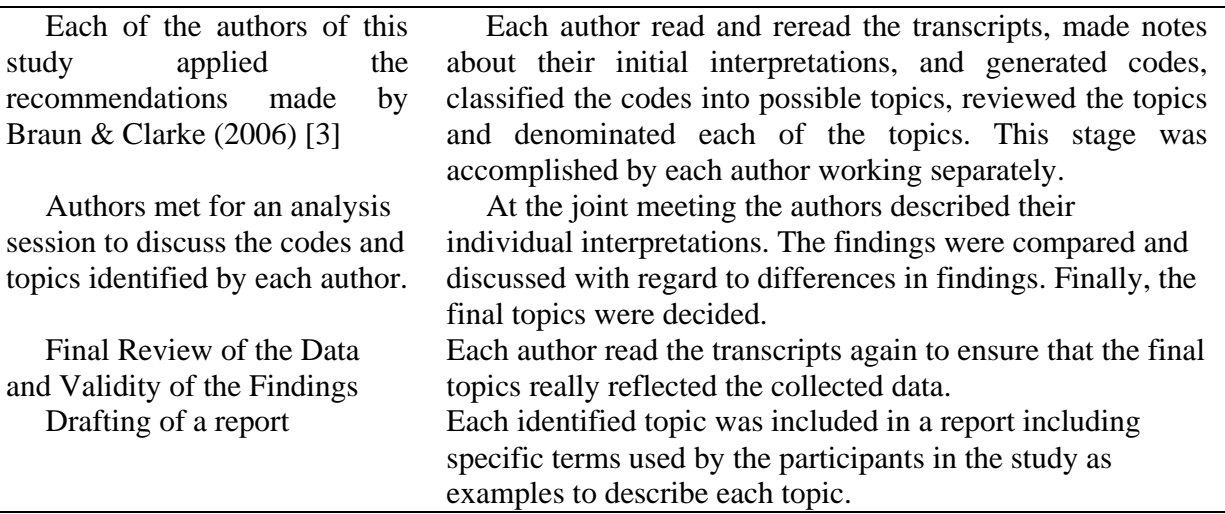

\section{$5 \quad$ Findings of the study}

Something unexpected always happens and money causes me stress. The participants in this study considered money as something that caused stress. They said that "excessive spending of money makes us sleepless ..." because "... money does not come that easy". For the families of this sampling, spending money symbolizes fear 
for tomorrow or for the future. Families of the respondents had to list their spending according to the priorities. According to them, spending on their children's schooling was considered a priority. Other students described the difficult financial moments that their family has experienced: "... there have been months when we could not afford to get the medicines for our sick parents or brothers and sisters". Two of the students stated that: "Returning from emigration we ended up in poverty ..., years ago we emigrated to a neighboring country for a better life leaving behind everything, we even sold our house ... We were not fortunate and we had to come back and we started everything again from scratch." Today they have not managed to buy another dwelling and consequently a part of the scholarship they get goes to cover the cost of renting the dwelling for their family.

The savings and financial challenges of the students' families. The participants in this study stated that none of their family members had any money saved as a result of limited income or even mismanagement of limited resources. During the interviews the students found it difficult to remember the moments when their families had conveyed them any messages about the savings or financial goals. An opinion expressed by family members in relation to money saving is "Children should not be taught with the sense of money saving, as they may be withdrawn from their entertainment." However, some of the youngsters stated that their parents encouraged them to save money in the future. As for long-term financial goals, they reported that their parents had always wanted them to attend higher studies in the hope that in the future this would enable them to get a well-paid job. A statement used to represent a common opinion is "My mother always wanted me to pursue higher studies ... She expects me to get a good job in the future."

The financial status of the family. In describing the financial situation of their families, most respondents stated that their families were experiencing financial difficulties. Some of the students made a statement like "Money in our family is never enough to cover our monthly expenses".

Financial education and savings. The students that participated in this study had attended secondary school in Albania. They stated that they had not attended the compulsory course "Personal Finances in Your Hands" during high school. Even in higher education, they said that they that had not attended any subject related to financial education. Some students said "I think that it would be beneficial to be taught this subject as in this way I would not only learn new concepts in the field of finance but it will help me learn how I should save money." Most students are of the opinion that money should be saved, but this as they say is possible only if some income remains after having covered the necessities. The students of the Faculty of Economics say that the right form of savings is to have a savings account or a bank deposit. However, none of them possessed a savings account ".. in the future I will have my savings account". A student from the Faculty of Economics said"... I've just heard about 2-year bonds and private investment funds; I consider it as a good opportunity to invest". During the interviews some students think that in the future they will have their own business. Although the students of the Faculty of Foreign Languages agree on the financial purpose of saving money, they said that they sometimes feel uncertain about depositing their monetary means in the banking system operating in Albania in the future when they might have got a job. "Money, for me is safer at home than in the banking system". 
Regarding the factors that influence the lack of students' savings they said "... thanks to the income I received from my part-time job I have helped my family, so I had enough money to cover my living expenses and family's ones. I've been trying to work long hours to put some money aside". Another student stated, “... every month I get a fixed amount from my family to cover the costs of the study, as soon as I take this money I deposit a part of it in my savings box in order not to spend it". While interviewing the students who stated that they have a job and save money, they were asked to identify the reasons why they saved. A student said, "To spend money on things like coffee, parties, entertainment is not worth it, as they last very shortly and money is wasted in vain". Someone else stated that "Saving money gives me confidence for the future when I might be faced with an emergency situation".

\section{Conclusions and Recommendations}

While describing their family's financial situation, the students stated that their families have had financial difficulties for years. Some commented that their families found it difficult to afford necessary expenses for food, clothing, and rent payments, and they had to list the costs according to the priority. This situation is a consequence of job insecurity and lack of opportunities to obtain other sources of income, or lack of price stability or even returning from emigration and having to start everything from scratch.

Nine students said that they were the only child of the family who continued their studies, while their sisters and brothers had had to work at an early age to cover family expenses with regard to payment of bills, financial emergencies or even to finance their studies. They expressed their appreciation and also their surprise at how the family had made funding available for their studies even though the financial conditions of their families were very difficult. However, for all the interviewees that participated in this study, funding for higher education was a major concern for their families, despite the fact that they had not planned or put aside any money earlier in the past to accomplish this goal. While the employed respondents, also considering the fact that they came from low-income families, stated that they provided part of the income from their employment to their families to cover the necessary living expenses and as a consequence they could not save at all. Meanwhile other students said they only saved after covering all their expenses. This conclusion suggests that state institutions should consider the option of compensating with economic aid the low-income families whose children attend higher studies so that these families can meet their needs and have the opportunity to save for the future as well. It also supports the strong link that exists between the financial behavior of the children and their families.

The participants in the study said that their family members had not saved any money because of their limited income or even mismanagement of limited resources. They argued that economic crises, job losses, return from emigration, the illness of one parent, death of a family member, parents' divorce, or even a lack of a financial plan for the future were the main causes hindering savings in their families. In the face of financial hardships and lack of any savings, their families followed some ways to cover expenses, such as borrowing money from their relatives, getting a second job 
often in the informal labor market, postponing the payment of the goods they purchase. This conclusion suggests that, as the concept and practice of financial advice for businesses have been established, private or state structures should be set up to provide the necessary counseling for the well-management of personal finances or structures that may aim at lifelong financial education. Such structures should be equipped with professional knowledge both in the field of finance and financial behavior, as a significant element for financial decision-making. Just as there are financial education programs for young people, there should also be financial education programs for adults.

The students that participated in this study often gave psychological and emotional meaning to the saving of money. Saving money gave them security and serenity for the future. They said they would like to avoid difficult financial situations similar to those their families have experienced. As their long-term financial goals they listed setting up their own business or possessing assets. According to them this implies that property can not be obtained only through the money you earn from your job or other ways, but also through investment.

Financial literacy will also lead to the improvement of financial services to financially excluded groups such as the households with economic assistance. Understanding the concept that the households with economic assistance have about savings or various financial products, banking institutions can tailor their services to respond to their needs. It is suggested that the banking system should modify strategies and also influence public financial education in order to increase the confidence of this group referring to depositing their monetary means in the banking system

With regard to financial education, all students expressed their willingness to pursue a Personal Finance course at this stage of their life cycle, therefore inclusion of financial knowledge while undertaking actions or financial behaviors, linking theory to concrete actions in practice. Providing information simultaneously with banking experience would help them connect their behavior with knowledge.

The students of the Faculty of Economics demonstrated high levels of financial knowledge due to the financial education they have received during their studies at this faculty, accompanied with the first experiences in money management. In describing their financial behavior, they said that planning of the income should not be limited to saving money, but also to investing it. Whereas the students of the Faculty of Foreign Languages lacked basic knowledge on economy and finance, they did not know the concepts such as time value of money, inflation, and lacked the information on investment alternatives offered in the financial market in Albania. As a result, banking institutions need to modify their strategies to increase the level of savings, deposits or even investments of this group.

In general, the findings of this study are important referring to financial education of the family. Understanding the factors such as the students' financial education, parental influence on their financial education, or emotions may contribute to clarifying the way of their financial decision making. Since the government policies still refer to the issue of savings and investments as individuals' responsibility then financial education needs to be given sufficient importance at an earlier age. Findings suggest that some students do not want to replicate their parents' behavior and experience financial difficulties. They were motivated to avoid financial challenges in 
the future but it should be pointed out that they are experiencing more social and economic barriers than their peers with higher-income.

Considering all these findings of previous studies, the present study is imperative to assist in formulating policies specially targeted at youth after analyzing the impact of specific socio-economic and demographic factors of youth on their financial literacy level. Future research and practice must identify which ages and developing stages are most appropriate to introduce and incorporate financial education programs as well as what content is appropriate to introduce at each developmental stage.

\section{References}

1 Atkinson, A., \& Messy, F.-A. (2013). Promoting Financial Inclusion through Financial Education. OECD/INFE Evidence, Policies and Practice, OECD Working Papers on Finance Insurance and Private Pensions, No. 34

2 Avard, S., Manton, E., English, D., \& Walker, J. (2005). The financial knowledge of college freshman. College Student Journal, 321-339.

3 Braun, V., \& Clarke, V. (2006). Using thematic analysis in psychology. Qualitative Research in Psychology, 2 (3), 77-101.

4Chinen, K., \& Endo, H. (2012). Effects of attitude and background on personal financial ability: A student survey in the United States. International Journal of Management (29 (1)), 33-45.

5 Cole, S., Sampson, T., \& Zia, B. (2009). Prices or Knowledge? What Drives Demand for Financial Services in Emerging Markets? The Journal of Finance, Vol. 66 (No. 6), 19331967.

6Creswell, J. W. (2009). Research Design: Qualitative, Quantitative, and Mixed Methods Approaches. Thousand Oaks, CA: Sage Publication.Inc.

7Flick, U. (2009). An Introduction to Qualitative Research. London: Sage Publications, Ltd.

8 Gallo, E., Gallo, J. J., \& Gallo, K. J. (2011). Silver Spoon Kids: How Successful Parents Raise Responsible Children. New York: : McGraw-Hill.

9Heckman, S. J., \& Grable, J. E. (2011). Testing the role of parental debt attitudes, student income, dependency status, and financial knowledge have in shaping financial selfefficacy. College Student Journal (45 (1)), 51-64.

10 Huston, S. (2010). Measuring financial literacy. The Journal of Consumer Affairs, 296316.

11 Inc., S. \&. (2014). Standard \& Poor's Ratings Services Global FinLit Survey. Retrieved from Standard \& Poor's Ratings Services Global FinLit Survey: http://www.FinLit.MHFI.com.

12 Kezar, A., \& Yang, H. (2010). The importance of financial literacy. About Campus, 14 (6), 15-21.

13 Lusardi, A. (2008). Financial Literacy: An Essential Tool for Informed Consumer Choice. NBER Working Paper No. 14084.

14 Lusardi, A., \& Mitchell, O. S. (2011). Financial literacy and retirement planning in the United States. Journal of Pension Economics and Finance, 509-525.

15 Lusardi, A., \& Mitchell, O. S. (2007). Financial literacy and retirement preparedness: evidence and implications for financial education. Business Economics, 35-44.

16 Lusardi, A., \& Mitchell, O. S. (2013). The Economic Importance of Financial Literacy: Theory and Evidence. NBER Working Paper No. 18952.

17 Lusardi, A., \& Tufano, P. (2009). Debt Literacy, Financial Experiences, and Overindebtedness. NBER Working Paper No. 14808. 
18 Lusardi, A., Mitchell, O. S., \& Curto, V. (2010). Financial Literacy among the Young. Journal of Consumer Affairs, 2 (44), 358-380.

19 Nano, D. (2014). Aftësia e studentë në Shqipëri. Durrës: Dizertacion Doktorature.

20 OECD. (2013). Financial literacy and inclusion: Results of OECD/INFE survey across countries and by gender. Paris, France: OECD Centre.

21 Peng, T.-C. M., Bartholomae, S., Fox, J. J., \& Cravener, G. (2007). The Impact of Personal Finance Education Delivered The Impact of Personal Finance Education Delivered. Journal of Family and Economic Issues (28 (2)), 265-284.

22 Perry, V. G., \& Morris, M. D. (2006). Who Is in Control? The Role of SelfPerception, Knowledge, and Income in Explaining Consumer Financial Behavior. The Journal of Consumer Affairs, 39 (2), 299-313.

23 Remund, D. (2010). Financial literacy explicated: the case for a clearer definition in an increasingly complex economy. The Journal of Consumer Affairs, Vol. 44 (2), 276-295.

24 Rooij, M. v., Lusardi, A., \& Alessie, R. (2011). Financial Literacy, Retirement Planning, and Household Wealth. De Nederlandsche Bank NV, Working Paper No. 313.

25 Shim, S. B. (2009). Financial socialization of first-year college students: The roles of parents work, and education. Journal of Youth and Adolescence, 1457-1470.

26 Shim, S., Barber, B. L., Card, N. A., Xiao, J. J., \& Serido, J. (2010). Financial socialization of first-year college students: the roles of parents, work, and education. Journal of Youth and Adolescence, 39, 1457-1470.

27 Shim, S., Serido, J., Bosch, L., \& Tang, C. (2013). Financial Identity-Processing Styles Among Young Adults: A Longitudinal Study of Socialization Factors and Consequences for Financial Capabilities. The Journal of Consumer Affair, 47 (1), 128-152.

28 World Bank, W. (2009). The Case for Financial Literacy in Developing Countries. Promoting Access to Finance by Empowering Consumers,. Washington, DC: The World Bank.

29 World Bank (2014). A survey on access to and use of financial services in 152 countries around the world. World Bank Global Financial Development Report on Financial Inclusion. The 2014 Global Financial (Global Findex) Database. Washington, DC: The World Bank. 